\begin{tabular}{|c|c|c|}
\hline 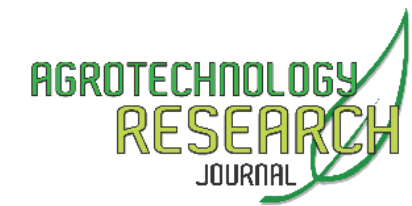 & $\begin{array}{c}\text { Agrotech Res J, June } 2019,3(1): 44-49 \\
\text { AGROTECHNOLOGY RESEARCH } \\
\text { JOURNAL }\end{array}$ & $\begin{array}{l}\text { ISSN 2655-7924 (Print) } \\
\text { ISSN 2614-7416 (Online) } \\
\text { https://jurnal.uns.ac.id/arj } \\
\text { doi:10.20961/agrotechresj.v3i1.30396 }\end{array}$ \\
\hline
\end{tabular}

\title{
Pengaruh Biochar terhadap Pertumbuhan Padi dalam Sistem Aerobik
}

\author{
Suli Suswana ${ }^{1}$ \\ ${ }^{1}$ Department of Agrotechnology, Faculty of Agriculture, Universitas Islam Nusantara, Bandung, Indonesia \\ ${ }^{*}$ Corresponding Author: \\ E-mail: sulisuswana@gmail.com
}

Received 27 May 2019; Accepted 25 June 2019; Published 30 June 2019

\begin{abstract}
An application of biochar to the intensive weathered soils potentially can change physical and chemical properties of the soils, improved soil function and increased yield of crops. A meta-analyses evaluation showed a significant correlation between biochar and plants productivity, that means there are benefits of biochar application to the soils on plants productivities, that was increased 10\%. This experiment was used Randomized Completed Block Design with 8 treatments and 3 replications. The treatments are: contr), 20 ton biochar ha ${ }^{-1}, 40$ ton biochar ha ${ }^{-1}, 50$ ton biochar ha-1, 60 ton biochar ha-1, 10 ton biochar +10 ton poultry litter ha-1, 20 ton biochar +20 ton poultry litter ha-1, 30 ton biochar +30 ton poultry litter ha-1. The results showed biochar 20 ton ha-1 could increase significantly of plant heigh, number of punicles per clump, and the weight dried straw per clump. Whereas, application combination 2030 ton biochar ha- ${ }^{-1}+20-30$ ton poultry litter ha-1 could increase amount of tillers per clump, amound of punicles per clump, and weight dried straw (total biomass) per clump significantly.
\end{abstract}

Keywords: Biochar; organic matter; decomposition; aerobic

(C) 2019 Agrotechnology Research Journal

Cite This As: Suswana S. 2019. Pengaruh Biochar terhadap Pertumbuhan Padi (Oryza sativa I.) dalam sistem aerobik. Agrotech Res J 3(1):43-49. https://doi.org/10.20961/agrotechresj.v3i1.30396

\section{PENDAHULUAN}

Peningkatan produksi dan swasembada padi dan jagung berkelanjutan merupakan sasaran utama dari program dan rencana strategis Kementan RI tahun 2015-2019. Namun dalam implementasi banyak kendala, diantaranya ketersediaan sumberdaya lahan potensial makin terbatas akibat konversi dan degradasi lahan (Djaenudin, 2008). Konversi lahan sawah produktif menjadi lahan non pertanian berlangsung dengan laju sebesar 96.512 ha tahun ${ }^{-1}$. Sementara pencetakan sawah baru setiap tahun rata-rata 20.00030.000 ha (Mulyani et al. 2017). Luas lahan terdegradasi terus bertambah, pada tahun 1993 sekitar 18 juta ha, pada tahun 2003 meningkat menjadi 23,20 juta ha (Baja, 2005; Djaenudin, 2008). Bagi ketahanan pangan nasional, konversi lahan sawah merupakan ancaman serius yang sulit dihindari (Mulyani et al., 2017) karena desakan kebutuhan lahan untuk pembangunan di sektor non-pertanian.

Lahan tersedia untuk peningkatan produksi pangan, umumnya berupa lahan sub optimal, yang memerlukan input tinggi agar dapat berproduksi secara optimal

This is an open access article

Licensed under the Creative Commons Attribution

International License CC-BY-SA 4.0

(c) EY-SA
(Mulyani et al., 2016). Lahan kering merupakan tipe lahan sub optimal (Mulyani dan Sarwani, 2013), yang dapat dijadikan alternatif perluasan areal tanam. Luas total lahan kering di Indonesia 144,5 juta ha dan yang sesuai untuk pertanian seluas 99,6 juta ha (Mulyani et al., 2017) , dan yang potensial untuk tanaman semusim 25,40 juta ha (Djaenudin, 2008). Sebagian besar lahan kering termasuk pada wilayah beriklim basah (curah hujan $>2.000 \mathrm{~mm}^{\text {tahun }}{ }^{-1}$ ), dan tergolong ke dalam ordo Ultisol, Oxisol, dan Inceptisol (Soil Survey Staff, 2015; Mulyani et al., 2017). Lahan tersebut umumnya identik dengan lahan kering masam yang ditandai dengan kemasaman tanah tinggi, mengalami pencucian kationkation basa intensif, kejenuhan basa rendah dan miskin unsur hara (Subagyo et al., 2000; Mulyani et al., 2017), sehingga umumnya memiliki kesuburan dan produktivitas rendah. Oleh karena itu, memerlukan inovasi teknologi tepat guna yang relevan untuk mengatasi faktor-faktor pembatas yang ada.

Lahan sub optimal adalah lahan yang secara alamiah produktivitas rendah dan ringkih (fragile) dengan berbagai kendala akibat faktor inheren (tanah, bahan induk) maupun faktor eksternal akibat iklim yang ekstrim, termasuk lahan terdegradrasi akibat eksploitasikurang bijak. Secara biofisik, lahan sub optimal memiliki berbagai kendala dan faktor pembatas dalam pemanfaatan sehingga tingkat kesuburan dan produktivitas rendah (Mulyani et al., 2016). 
Bahan organik tanah memiliki pengaruh positif terhadap hampir semua karakteristik tanah. Adanya gejala-gejala tanah terdegradasi dan miskin kualitas biasanya berkorelasi langsung dengan deplesi bahan organik tanah (Magdoff and Van As, 2009). Akan tetapi, pencampuran biomasa organik pada tanah di daerah tropika basah cepat terdekomposisi, sehingga hanya memberikan solusi jangka pendek (Haefele, 2007. Biochar merupakan produk padat hasil pirolisis dari material organik (Mehmood et al., 2017; Clough et al., 2013) yang secara intrinsik resisten terhadap dekomposisi mikrobial (Clough et al., 2013; Kuzyakov et al., 2000; Marschner et al., 2000), sehingga secara potensial dapat tetap berada di dalam tanah selama ratusan tahun (Preston and Schmidth 2006). Biochar terbukti mempunyai pengaruh yang lebih kekal terhadap $\mathrm{pH}$ tanah dari pada $\mathrm{CaCO}_{3}$; serta dapat berpengaruh lebih besar terhadap siklus $\mathrm{N}$ ketimbang aplikasi kapur (Teutscherova et al. (2017). Biochar jerami padi signifikan meningkatkan $\mathrm{pH}$, konduktivitas elektrik, kapasitas tukar kation tanah, diversitas bakterial, aktivitas enzim katalase, kapasitas menahan air, biomasa mikrobial, netto mineralisasi $\mathrm{N}$, laju respirasi tanah, dan menurunkan pencucian N (Yang et al., 2015; $\mathrm{Xu}$ et al., 2016). Pada tanah yang telah mengalami pelapukan lanjut biochar dapat merubah sifat-sifat fisikokimia tanah, memperbaiki fungsi tanah dan meningkatkan hasil tanaman (Mehmood et al., 2016). Biochar juga dapat mensequester sejumlah besar Cbiogenik, menghambat pelepasan karbon ke atmosfir (Cheng et al., 2008; Budai et al., 2016; Goenadi dan Santi, 2017). Kandungan C-stabil meningkat pasca pemberian biochar, dimana C-biochar tetap ada (persistent) dengan waktu paruh 60 kali lebih lama dibandingkan dengan bahan organik asalnya (Budai et al., 2016). Pada tanah pertanian, biochar terbukti meningkatkan total karbon organik, kapasitas tukar kation, dan menurunkan kandungan $\mathrm{Cd}$ dan $\mathrm{Pb}$ dapat diekstrak (Bian et al., 2014; Xie et al., 2014). Hasil evaluasi meta-analisis menunjukkan bahwa secara statistik hubungan antara biochar dan produktivitas tanaman adalah nyata positif, dengan rerata umum sebesar $10 \%$. Pengaruh terbesar adalah pada tanah masam (14\%) dan pada tanah ber-pH netral (13\%), pada tanah dengan tekstur kasar (10\%) dan medium (13\%). Takaran perlakuan biochar $10,25,50$ and 100 ton ha-1 menunjukkan pengaruh signifikan terhadap peningkatan produksi tanaman (Jeffery et al., 2011). Pemberian 22,4 ton biochar ha $\mathrm{a}^{-1}$ meningkatkan total karbon organik tanah 1,4 kali lipat dan meningkatkan $\mathrm{Mn}$ tersedia tanah 1,5 kali lipat dibandingkan dengan kontrol; penambahan biochar dicampur dengan pupuk kandang memberikan pengaruh sinergistik meningkatkan Mn-tersedia dan Ktersedia dibandingkan dengan kontrol, serta dapat menghambat kehilangan C-organik tanah (Lentz dan Ippolito, 2011), dan menurunkan alumunium dapat ditukar (Lehmann et al., 2011; Chan et al., 2007). Media tumbuh bibit kelapa sawit dengan komposisi $40 \%$ top soil + 40 biochar sekam padi $+20 \%$ kompos memberikan pertumbuhan bibit yang paling baik (Basri et al, 2015), formula biochar limbah pertanian dengan kompos 25$50 \%$ meningkatkan tinggi tanaman jagung pada tanah mineral non masam, sedangkan pada tanah mineral masam dapat diaplikasikan biochar dengan atau tanpa kompos (Nurida et al., 2013). Pemberian biochar 2,5 ton ha $^{-1}$ nyata meningkatkan K-potensial dan serapan $\mathrm{K}$ pada fase primordia, dan produksi biomasa kedelai, serta interaksinya dengan pemupukan nyata meningkatkan bobot kering bintil akar dan hasil bobot kering kedelai sebesar $16 \%$ (Hartatik et al., 2015). Sumber bahan baku yang fisibel untuk produksi biochar adalah jerami dan sekam padi yang sering ditinggalkan setelah panen. Total residu produksi padi di Asia setiap tahunnya diestimasi 549 juta ton jerami dan 110 juta ton sekam padi (Haefele, 2007).

Informasi terbatas tentang bukti nyata manfaat positif penggunaan biochar untuk memperbaiki sifat-sifat fisikokimia tanah dan meningkatkan produktivitas tanaman secara berkelanjutan menjadi penyebab penghambat proses trasfer/translasi teknologi penggunaan biochar sebagai bahan pembenah tanah, baik di kalangan ilmuwan maupun pengguna (petani). Penelitian ini bertujuan untuk mengkonfirmasi pengaruh dari biochar dan manfaat persistensi dengan mengkaji pengaruh biochar terhadap pertumbuhan dan hasil padi (Oryza sativa L.) dalam sistem aerobik, yang akan dilanjutkan dengan mengkaji pengaruh residu pada musim tanam berikutnya. Penelitian ini penting, karena jika ternyata hasil penelitian ini signifikan memberikan pengaruh positif terhadap hasil tanaman, maka temuan ini akan menjadi bagian dari solusi untuk mengatasi ketidakberlanjutan peningkatan produktivitas lahan sub optimal.

\section{BAHAN DAN METODE}

Penelitian dalam bentuk percobaan pada media tanam di Fakultas Pertanian Uninus Jl. Soekarno Hatta 530 Kota Bandung pada ketinggian tempat sekitar 670 meter di atas permukaan laut, mulai dari bulan September sampai Desember 2018. Percobaan menggunakan Rancangan Acak Kelompok dengan 8 perlakuan dan 3 ulangan. Perlakuan adalah pemberian biochar sekam padi sebagai berikut: kontrol/tanpa biochar, 20 ton biochar ha ${ }^{-1}, 40$ ton biochar ha- ${ }^{-1}, 50$ ton biochar ha ${ }^{-1}, 60$ ton biochar ha ${ }^{-1}, 10$ ton biochar +10 ton pupuk kandang ayam ha ${ }^{-1}, 20$ ton biochar +20 ton pupuk kandang ayam ha $^{-1}, 30$ ton biochar +30 ton pupuk kandang ayam ha- ${ }^{-1}$. Pupuk N, P, dan K berturut-turut dalam bentuk urea, SP-36 dan $\mathrm{KCl}$ diberikan sebagai pupuk dasar sebanyak $200 \mathrm{~kg} \mathrm{~N}^{-1}, 100 \mathrm{~kg} \mathrm{P}_{2} \mathrm{O}_{5} \mathrm{ha}^{-1}$, dan $100 \mathrm{~kg}$ $\mathrm{K}_{2} \mathrm{O}$ ha $^{-1}$. Untuk menjaga agar kondisi media tumbuh tidak mengalami cekaman kekeringan, setiap hari dilakukan penyiraman, kecuali bila terjadi hujan. Varietas padi yang digunakan yaitu varietas Situbagendit.

\section{HASIL DAN PEMBAHASAN \\ Tinggi Tanaman}

Pemberian biochar 20 dan 60 ton ha-1, serta campuran 10 ton biochar +10 ton pupuk kandang ayam ha-1, 20 ton biochar +20 ton pupuk kandang ayam ha ${ }^{-1}, 30$ ton biochar +30 ton pupuk kandang ayam ha- ${ }^{-1}$, nyata meningkatkan tinggi tanaman menjelang primordia (10 minggu setelah tanam) dibandingkan dengan kontrol (Tabel 1). 
Tabel 1. Pengaruh biochar terhadap pertumbuhan tinggi tanaman

\begin{tabular}{lcccc}
\hline \multirow{2}{*}{ Dosis Biochar dan Biochar + PL (ha $\left.{ }^{-1}\right)$} & \multicolumn{4}{c}{ Tinggi Tanaman (cm) pada umur (MST) } \\
\cline { 2 - 5 } & 4 & 6 & $59,17 \mathrm{a}$ & $63,50 \mathrm{a}$ \\
\hline 0 & $30,50 \mathrm{a}$ & $45,8 \mathrm{a}$ & $67,17 \mathrm{bc}$ & $72,17 \mathrm{bc}$ \\
20 ton & $34,17 \mathrm{ab}$ & $52,08 \mathrm{abc}$ & $70,50 \mathrm{abc}$ \\
40 ton & $32,17 \mathrm{ab}$ & $49,33 \mathrm{ab}$ & $65,17 \mathrm{ab}$ & $70,67 \mathrm{abc}$ \\
50 ton & $34,25 \mathrm{ab}$ & $53,68 \mathrm{abc}$ & $67,50 \mathrm{bc}$ & $74,33 \mathrm{bc}$ \\
60 ton & $35,17 \mathrm{abc}$ & $52,08 \mathrm{abc}$ & $67,33 \mathrm{bc}$ & $74,33 \mathrm{bc}$ \\
10 ton biochar + 10 ton PL & $36,68 \mathrm{bcd}$ & $54,83 \mathrm{bc}$ & $70,67 \mathrm{bc}$ & $73,67 \mathrm{c}$ \\
20 ton biochar + 20 ton PL & $41,73 \mathrm{~d}$ & $60,17 \mathrm{c}$ & $73,83 \mathrm{c}$ & $76,17 \mathrm{bc}$ \\
\hline
\end{tabular}

Keterangan: $\mathrm{PL}=$ poultry litter atau pupuk kandang ayam; MST = minggu setelah tanam; Angka rata-rata yang diikuti huruf kecil yang sama tidak berbeda nyata berdasarkan uji Jarak Berganda Duncan pada taraf 5\%.

Berdasarkan hasil penelitian menunjukkan bahwa pemberian 10 ton biochar ha-1 mampu meningkatkan pertumbuhan tanaman. Tinggi tanaman pada campuran 10 ton biochar +10 ton pupuk kandang ayam ha-1 tidak berbeda nyata dibandingkan dengan yang diberi 20 ton biochar ha-1. Demikian halnya yang diberi 20 ton biochar + 20 ton pupuk kandang ayam ha-1 tidak berbeda nyata dibandingkan dengan pada pemberian 40 ton biochar ha $^{-1}$. Hasil ini menunjukkan bahwa efek sinergistik dari pemberian biochar dikombinasikan dengan pupuk kandang ayam terhadap pertumbuhan tinggi tanaman tidak signifikan. Pemberian biochar 20 ton ha-1, baik secara tersendiri maupun dengan cara dicampur dengan pupuk kandang mampu meningkatkan tinggi tanaman padi secara signifikan dibandingkan dengan kontrol. Tinggi tanaman diberi biochar 20 ton ha-1 dibandingkan dengan 10 ton biochar +10 ton pupuk kandang ayam ha1 tidak berbeda nyata. Hal ini memperkuat bukti bahwa efek sinergistik dari pencampuran biochar dengan pupukkandang tidak signifikan, yang berarti tidak sejalan dengan hasil penelitian Lentz dan Ippolito (2011) yang melaporkan bahwa penambahan biochar dicampur dengan pupuk kandang memberikan pengaruh sinergistik meningkatkan Mn-tersedia dan K-tersedia dibandingkan dengan kontrol.

Mengingat bahwa semua tanaman diberi pupuk dasar N, P, dan K sama, maka dapat diduga bahwa fungsi utama biochar bukan sebagai penyumbang unsur hara tanaman melainkan lebih berperan sebagai pembenah tanah, yang mengubah kondisi fisik dan biokimia tanah menjadi lebih kontributif terhadap peningkatan ketersediaan dan serapan unsur-unsur hara tanaman. Hartatik et al. (2015) menyatakan bahwa pemberian 2,5 ton biochar ha ${ }^{-1}$ tidak signifikan meningkatkan tinggi tanaman kedelai pada saat primordia, tetapi signifikan meningkatkan K-potensial di dalam tanah. Peneliti tersebut menduga bahwa pengaruh biochar karena dosis masih kurang. Hasil penelitian ini membuktikan bahwa pemberian biochar dengan dosis yang lebih tinggi (20 ton ha-1) nyata meningkatkan tinggi tanaman dibandingkan dengan kontrol. Hasil penelitian Basri et al. (2015) menunjukkan bahwa pertumbuhan bibit kelapa sawit (bobot kering tanaman) pada media tumbuh dengan komposisi $40 \%$ topsoil $+40 \%$ biochar sekam padi $+20 \%$ kompos nyata lebih tinggi dibandingkan dengan media tumbuh $100 \%$ topsoil, yang berarti bahwa diperlukan dosis biochar yang tinggi untuk mampu memperbaiki kondisi media tumbuh bibit kelapa sawit. Conte (2014) menyatakan bahwa biochar mengubah sifat-sifat fisika-kimia tanah, dengan cara demikian itu biochar mempengaruhi kesuburan tanah. Lentz dan Ippolito (2011) melaporkan bahwa pemberian biochar 22,4 ton ha-1 meningkatkan total karbon organik tanah 1,4 kali lipat dan meningkatkan $\mathrm{Mn}$ tersedia tanah 1,5 kali lipat dibandingkan dengan kontrol.

\section{Jumlah Anakan per Rumpun}

Pada 10 minggu setelah tanam, jumlah anakan per rumpun dari pemberian biochar $20,40,50$, dan 60 ton ha $^{-1}$ dan campuran 10 ton biochar +10 ton pupuk kandang ayam ha ${ }^{-1}$ tidak berbeda nyata dengan kontrol. Sedangkan jumlah anakan per rumpun pada pemberian campuran 20 ton biochar +20 ton pupuk kandang ayam ha-1 dan 30 ton biochar +30 ton pupuk kandang ayam ha-1 nyata lebih tinggi dibandingkan dengan kontrol (Tabel 2).

Tabel 2. Pengaruh biochar terhadap jumlah anakan per rumpun

\begin{tabular}{|c|c|c|c|c|}
\hline \multirow{2}{*}{ Dosis Biochar dan Biochar + PL (ha-1) } & \multicolumn{4}{|c|}{ Jumlah Anakan per Rumpun pada umur (MST) } \\
\hline & 4 MST & 6 MST & $8 \mathrm{MST}$ & $10 \mathrm{MST}$ \\
\hline 0 & $22,33 \mathrm{a}$ & $36,17 \mathrm{a}$ & $41,67 \mathrm{a}$ & $43,50 \mathrm{a}$ \\
\hline 20 ton & $27,00 \mathrm{ab}$ & $41,67 \mathrm{a}$ & $47,50 \mathrm{ab}$ & $49,83 a b$ \\
\hline 40 ton & 23,33 a & $38,00 \mathrm{a}$ & $46,67 \mathrm{ab}$ & $48,33 a b$ \\
\hline 50 ton & $23,00 \mathrm{a}$ & $39,17 \mathrm{a}$ & $50,50 a b$ & $52,33 a b$ \\
\hline 60 ton & $23,00 \mathrm{a}$ & $39,83 \mathrm{a}$ & $49,00 \mathrm{ab}$ & $51,50 \mathrm{ab}$ \\
\hline 10 ton biochar +10 ton PL & $27,00 \mathrm{ab}$ & $43,33 \mathrm{a}$ & $49,67 a b$ & $50,67 \mathrm{ab}$ \\
\hline 20 ton biochar +20 ton $\mathrm{PL}$ & $31,17 \mathrm{~b}$ & $45,33 \mathrm{a}$ & $54,67 \mathrm{~b}$ & $57,17 b$ \\
\hline 30 ton biochar +30 ton $\mathrm{PL}$ & $33,83 \mathrm{~b}$ & $45,83 \mathrm{a}$ & $56,33 \mathrm{~b}$ & $57,50 \mathrm{~b}$ \\
\hline
\end{tabular}

Keterangan: $\mathrm{PL}=$ poultry litter atau pupuk kandang ayam; MST = minggu setelah tanam. Angka rata-rata yang diikuti huruf kecil yang sama tidak berbeda nyata berdasarkan Uji jarak berganda Duncan pada taraf $5 \%$. 
Jumlah anakan per rumpun pada pemberian kombinasi 20 ton biochar +20 ton pupuk kandang ayam ha $^{-1}$ tidak berbeda nyata dengan pada pemberian 40 ton biochar ha-1. Demikian halnya dengan pemberian 30 ton biochar + 30 ton pupuk kandang ayam ha-1 juga tidak berbeda nyata dibandingkan dengan pemberian 60 ton biochar ha-1. Fakta ini juga menunjukkan bahwa pengaruh sinergistik antara biochar dengan pupuk kandang ayam tidak signifikan terhadap pertumbuhan jumlah anakan.

\section{Umur Inisiasi Malai}

Pengaruh pemberian biochar, baik secara tersendiri maupun kombinasi dengan pupuk kandang ayam, tidak nyata terhadap umur inisiasi malai padi. Hal ini kemungkinan karena variabel umur isnisiasi malai ini kurang peka terhadap faktor kondisi lingkungan media tumbuh, dan mungkin lebih banyak dikendalikan oleh faktor genetik tanaman padinya. Umur inisiasi malai berkisar antara 80-83 hari setelah tanam. Yang relatif paling cepat adalah perlakuan pemberian kombinasi 20 ton biochar +20 ton pupuk kandang ayam ha-1.

\section{Jumlah Malai per Rumpun}

Perlakuan pemberian biochar berpengaruh nyata terhadap jumlah malai per rumpun dibandingkan dengan kontrol, kecuali perlakuan kombinasi 10 ton biochar +10 ton pupuk kandang ayam ha ${ }^{-1}$ (Tabel 3). Jumlah malai per rumpun pada perlakuan kombinasi 20 ton biochar + 20 ton pupuk kandang ayam ha ${ }^{-1}$ tidak berbeda nyata dengan perlakuan 40 ton biochar ha-1. Demikian juga pada perlakuan 30 ton biochar +30 ton pupuk kandang ayam ha-1 tidak berbeda nyata dengan perlakuan 60 ton biochar ha-1. Fakta ini menunjukkan bahwa efek sinergistik dari kombinasi biochar dengan pupuk kandang ayam cenderung tidak signifikan terhadap jumlah malai per rumpun. Bahkan jumlah malai per rumpun pada perlakuan kombinasi 10 ton biochar +10 ton pupuk kandang ayam ha-1 cenderung lebih rendah dari pada perlakuan 20 ton biochar ha-1. Hal ini mengindikasikan bahwa pada takaran yang lebih rendah, pemberian biochar sendiri lebih baik dari pada dicampur dengan pupuk kandang ayam.

Tabel 3. Pengaruh biochar terhadap jumlah malai per rumpun

\begin{tabular}{lr}
\hline $\begin{array}{l}\text { Dosis Biochar dan Biochar }+ \\
\text { PL }\left(\mathrm{ha}^{-1}\right)\end{array}$ & $\begin{array}{c}\text { Jumlah Malai per } \\
\text { Rumpun }\end{array}$ \\
\hline 0 & $34,17 \mathrm{a}$ \\
20 ton & $44,00 \mathrm{bcd}$ \\
40 ton & $44,33 \mathrm{~cd}$ \\
50 ton & $43,00 \mathrm{bcd}$ \\
60 ton & $40,83 \mathrm{bc}$ \\
10 ton biochar +10 ton $\mathrm{PL}$ & $40,00 \mathrm{ab}$ \\
20 ton biochar +20 ton $\mathrm{PL}$ & $45,17 \mathrm{~d}$ \\
30 ton biochar +30 ton $\mathrm{PL}$ & $46,67 \mathrm{~d}$ \\
\hline
\end{tabular}

Keterangan: $\mathrm{PL}=$ poultry litter atau pupuk kandang ayam; MST = minggu setelah tanam; Angka rata-rata yang diikuti huruf kecil yang sama tidak berbeda nyata berdasarkan Uji jarak berganda Duncan pada taraf $5 \%$.
Jumlah malai per rumpun tertinggi terobservasi pada kombinasi 30 ton biochar +30 ton pupuk kandang ayam ha $^{-1}$ kemudian disusul oleh kombinasi 20 ton biochar +20 ton pupuk kandang ayam ha-1, dan kedua perlakuan tersebut berbeda nyata lebih tinggi dibandingkan dengan kombinasi 10 ton biochar +10 ton pupuk kandang ayam ha $^{-1}, 60$ ton biochar ha-1, dan kontrol. Nampak bahwa pada dosis yang lebih tinggi, efek sinergistik dari kombinasi biochar dengan pupuk kandang nyata terhadap jumlah malai per rumpun.

Data pada Tabel 3 juga menggambarkan tren jumlah malai yang meningkat dari perlakuan kontrol - 20 ton biochar ha-1 - 40 ton biochar ha ${ }^{-1}$, tetapi cenderung menurun dari perlakuan 40 ton biochar ha ${ }^{-1}-50$ ton biochar ha-1 - 60 ton biochar ha ${ }^{-1}$. Fakta ini mengindikasikan bahwa dosis optimum biochar untuk padi dalam sistem aerobik berada di sekitar 40 ton ha-1.

\section{Bobot Kering Jerami per Rumpun}

Bobot kering jerami per rumpun pada perlakuan 20 ton biochar ha-1, kombinasi 20 ton biochar +20 ton pupuk kandang ayam ha-1, dan kombinasi 30 ton biochar + 30 ton pupuk kandang ayam ha-1 nyata lebih tinggi dibandingkan dengan kontrol (Tabel 4). Sedangkan pada perlakuan 40 ton biochar ha-1, 50 ton biochar ha-1, 60 ton biochar ha ${ }^{-1}$, dan kombinasi 10 ton biochar +10 ton pupuk kandang ayam ha-1 tidak berbeda nyata dibandingkan dengan kontrol. Bobot kering jerami per rumpun tertinggi terobservasi pada kombinasi 20 ton biochar +20 ton pupuk kandang ayam ha-1 ${ }^{-1}$ dan berbeda nyata dengan perlakuan lainnya, kecuali dengan kombinasi 30 ton biochar +30 ton pupuk kandang ayam ha $^{-1}$. Bobot kering jerami per rumpun pada kombinasi 30 ton biochar +30 ton pupuk kandang ayam ha-1 menduduki urutan kedua tertinggi, tetapi tidak berbeda nyata dengan 20 ton biochar ha-1, 40 ton biochar ha-1, 50 ton biochar ha-1, dan kombinasi 10 ton biochar +10 ton pupuk kandang ayam ha-1. Nampak bahwa bobot kering jerami pada kombinasi 20 ton biochar +20 ton pupuk kandang ayam ha ${ }^{-1}$ nyata lebih tinggi dari pada pemberian biochar 40 ton ha-1, yang berarti bahwa efek sinergistik kombinasi biochar dengan pupuk kandang signifikan. Akan tetapi, bobot kering jerami pada kombinasi 30 ton biochar +30 ton pupuk kandang ayam ha $^{-1}$ tidak berbeda nyata dengan pada pemberian biochar 60 ton ha-1, yang berarti bahwa efek sinergistik kombinasi biochar dengan pupuk kandang dalam kasus ini tidak signifikan. Jadi secara umum, efek sinergistik dari kombinasi biochar dengan pupuk kandang belum konsisten.

Tabel 4. Pengaruh biochar terhadap bobot kering jerami per rumpun padi

\begin{tabular}{lc}
$\begin{array}{l}\text { Dosis Biochar dan Biochar }+ \\
\text { PL }\left(\text { ha }^{-1}\right)\end{array}$ & $\begin{array}{c}\text { Bobot Kering Jerami } \\
\text { per Rumpun }(\mathrm{gram})\end{array}$ \\
\hline 0 & $34,00 \mathrm{a}$ \\
20 ton & $44,92 \mathrm{bc}$ \\
40 ton & $43,69 \mathrm{abc}$ \\
50 ton & $41,49 \mathrm{abc}$ \\
60 ton & $40,86 \mathrm{ab}$ \\
10 ton biochar +10 ton PL & $43,13 \mathrm{abc}$ \\
20 ton biochar +20 ton PL & $55,34 \mathrm{~d}$ \\
30 ton biochar +30 ton PL & $52,21 \mathrm{~cd}$ \\
\hline
\end{tabular}

Keterangan: $\mathrm{PL}=$ poultry litter atau pupuk kandang ayam; MST = minggu setelah tanam; Angka rata-rata yang diikuti huruf kecil yang sama tidak berbeda nyata berdasarkan Uji jarak berganda Duncan pada taraf 5\%. 
Pengaruh pemberian biochar 20 ton ha-1 terhadap bobot kering jerami per rumpun lebih tinggi dibandingkan dengan kontrol, tetapi dari takaran 40 ton ha- ${ }^{-1} 50$ ton $\mathrm{ha}^{-1}$ - 60 ton ha- ${ }^{-1}$ cenderung menurun, sekalipun tidak berbeda nyata. Hasil ini mengindikasikan bahwa pemberian biochar dengan takaran lebih dari 40 ton ha-1 kurang efektif. Pengaruh kurang menguntungkan pemberian biochar dengan dosis tinggi kemungkinan karena dengan berlebihnya dosis biochar itu mengakibatkan kondisi media tumbuh menjadi terlalu sarang, sehingga secara fisik kapasitas penahan airnya berkurang karena pori-pori makro proporsinya terlalu berlebih, sementara pori-pori mikro atau pori-pori kapiler yang berperan sebagai penahan air dari tarikan gravitasi relatif lebih rendah proporsinya.

\section{KESIMPULAN}

Penambahan biochar ke dalam media tumbuh di dalam pot dengan dosis 20 ton ha- ${ }^{-1}$ mampu meningkatkan tinggi tanaman, jumlah malai per rumpun, dan bobot kering jerami per rumpun dalam sistem aerobik secara signifikan, tetapi tidak signifikan meningkatkan jumlah anakan per rumpun dan umur inisiasi malai. Penambahan biochar dengan takaran lebih dari 40 ton ha-1 pada tanaman padi aerobik di dalam pot tidak efektif, karena mengakibatkan media tanam menjadi terlalu sarang.

Pemberian kombinasi biochar 20-30 ton + pupuk kandang 20-30 ton ha-1 pupuk kandang ayam mampu meningkatkan tinggi tanaman, jumlah anakan, jumlah malai per rumpun, dan bobot kering jerami secara signifikan, tetapi tidak signifikan meningkatkan umur inisiasi malai. Pencampuran biochar 20-30 ton ha ${ }^{-1}$ dengan cara dikombinasikan dengan pupuk kandang ayam memberikan pengaruh sinergistik yang tidak konsisten.

\section{DAFTAR PUSTAKA}

Baja S. 2005. The Use of Remote Sensing Technology for Agricultural Development Planning, South Celebes Case Study. Tech. and Applic. Conference Toward Competitive ASEAN, Jakarta 5-6 Sgustus 2005. Indonesian Agency for the Assessment and Application of Technology, Jakarta.

Basri AB, Chairunnas, Azis A. 2015. Pengaruh Media Tumbuh Biochar Sekam Padi terhadap Pertumbuhan Bibit Kelapa Sawit. B. Palma Vol. 16 No. 2: 195-202. Balai Pengkajian Teknologi Pertanian Aceh Jalan P. Nyak Makam No. 27 Lampineung Banda Aceh 23125.

Bian R, Josepha S, Cuia L, Pana G, Lia L, Liua X, Zhanga A, Rutlidgef $X$, Wonge $S$, Chiac $C$, Marjo $C$, Gong B, Munroe P, Donned S. 2014. A three-year experiment confirms continuous immobilization ofcadmium and lead in contaminated paddy field with biocharamendment. Journal of Hazardous Materials, 272: 121-128. www.elsevier.com/locate/jhazmat.

Budai, A, Rasse DP, Lagomarsino A, Lerch TZ, Paruch L. 2016. Biochar Persistence, Priming and Microbial Responses to Pyrolysis Temperature Series. Biol
Fertil Soils, 52: 749-761. DOI 10.1007/s00374-0161116-6. Springer.

Chan KY, Van Zwieten L, Meszaros I, Downie A, Joseph S. 2007. Agronomic values of greenwaste biochar as a soil amendment. Aust. J. Soil Res. 45:629-634. doi:10.1071/SR07109.

Cheng, CH, Lehmann J, Thies JE, Burton SD. 2008. Stability of black carbon in soils across a climatic gradient. J Geophys Res-Biogeosci 113:10. doi:10.1029/2007jg000642.

Clough TJ, Leo, Condron M, Kammann C, Müller C. 2013. A Review of Biochar and Soil Nitrogen Dynamics. Agronomy, 3: 275-293; doi:10.3390/agronomy3020275.

Conte, P. 2014. Biochar, soil fertility, and environment. Biol Fertil Soils (2014) 50:1175. DOI 10.1007/s00374-014-0973-0. Springer-Verlag Berlin Heidelberg.

Djaenudin D. 2008. Perkembangan Penelitian Sumberdaya Lahan dan Kontribusinya untuk Mengatasi Kebutuhan Lahan Pertanian di Indonesia. Jurnal Litbang Pertanian, Vol. 27 No. 4: 137-145. Balai Besar Penelitian dan Pengembangan Sumberdaya Lahan Pertanian. Bogor.

Gaspersz V. 1995. Teknik Analisis Dalam Penelitian Percobaan. Tarsito. Bandung.

Goenadi DH, Santi LP. 2017. Kontroversi Aplikasi dan Standar Mutu Biochar. Makalah Review. Jurnal Sumberdaya Lahan, Vol. 11 No. 1: 23-32.

Haefele SM. 2007. Black Soil-Green Rice. Rice Today. http://www.carbon-negative.us/docs/

Blacksoilgreenrice.pdf.

Hartatik W, Wibowo H, Purwani J. 2015. Aplikasi Biochar dan Tithoganic dalam Peningkatan Produktivitas Kedelai (Glycine max L.) pada Typic Kanhapludults di Lampung Timur. Jurnal Tanah dan Iklim Vol. 39 No. 1, Juli 2015: 51-62.

Jeffery, S, Verheijena FGA, Van der Veldea FGA, Bastos AC. 2011. A quantitative review of the effects of biochar application to soils on crop productivity using meta-analysis. Agriculture, Ecosystems and Environment, 144: 175-187. www.elsevier.com/locate/agee.

Kuzyakov Y, Friedel JK, Stahr K. 2000. Review of mechanisms and quantification of priming effects. Soil Biol Biochem 32:1485-1498.

Lehmann, J, Rillig MC, Thies J, Masiello CA, Hockaday WC, Crowley D. 2011. Biochar effects on soil biota e A review. Soil Biology \& Biochemistry, 43: 18121836. www.elsevier.com/locate/soilbio.

Lentz RD. Ippolito JA. 2011. Biochar and Manure Aff ect Calcareous Soil and Corn Silage Nutrient Concentrations and Uptake. Journal of Environmental Quality. 41: 1033-1043. doi:10.2134/jeq2011.0126. ASA, CSSA, SSSA. 5585 Guilford Rd., Madison, WI 53711 USA. 
Magdoff F. Harold Van As. 2009. Building Soils for Better Crops: Sustainable Soils Management. Handbook Series Book 10. Third Edition. Sustainable Agriculture Research and Education (SARE) program under cooperative agreements with USDA's National Institute of Food and Agriculture, University of Maryland and University of Vermont.

Marschner B, Brodowski S, Dreves A, Gleixner G, Gude A, Grootes PM, Hamer U, Heim A, Jandl G, Ji R, Kaiser K, Kalbitz K, Kramer C, Leinweber P, Rethemeyer J, Schaeffer A, Schmidth MWI, Schwark L, Wiesenberg GLB. 2008. How relevant is recalcitrance for thestabilization of organic matter in soils? J Plant Nutr Soil Sc 171:91-110. doi:10.1002/jpln.200700049.

Mehmood, K, Garcia EC, Schirrmann M, Ladd B, Kammann C, Wrage-Mönnig N, Siebe C, Estavillo JM, Mendizabal TF, Cayuela M, Sigua G, Spokas K, Cowie AL, Novak J, Ippolito JA, Borchard N. 2017. Biochar Research Activities and Their Relation to Development and Environmental Quality. A MetaAnalysis. Agron. Sustain. Dev., 37: 22. DOI 10.1007/s13593-017-0430-1. Springer.

Mulyani A. Sarwani M. 2013. Karakteristik dan Potensi Lahan Sub Optimal untuk Pengembangan Pertanian di Indonesia. Balai Besar Litbang Sumberdaya Lahan, Jl. Tentara Pelajar 12 Bogor 16114. Jurnal Sumberdaya Lahan Vol 7 No 1: 47-55.

Mulyani A, Nursyamsi D, Harnowo D. 2016. Potensi dan Tantangan Pemanfaatan Lahan Suboptimal untuk Tanaman Aneka Kacang dan Umbi. Prosiding Seminar Hasil Penelitian Tanaman Aneka Kacang dan Umbi 2016. Balai Penelitian Tanaman Aneka Kacang dan Umbi, Kotak Pos 66 Malang 65101.

Mulyani A, Nursyamsi D, Syakir M. 2017. Strategi Pemanfaatan Sumberdaya Lahan untuk Pencapaian Swasembada Beras Berkelanjutan. Makalah Review. Jurnal Sumberdaya Lahan Vol. 11 No. 1: 11 22. Balai Besar Litbang Sumberdaya Lahan Pertanian. Cimanggu, Bogor.

Nurida NL, Dariah A, Rachman A. 2013. Peningkatan kualitas tanah dengan pembenah tanah Biochar limbah pertanian. Jurnal Tanah dan Iklim 37(2):69-78. Balai Besar Penelitian dan Pengembangan Sumberdaya Lahan Pertanian, Badan Litbang Pertanian, Kementerian Pertanian.

Preston CM, Schmith MWI. 2006. Black (pyrogenic) carbon: a synthesis of current knowledge and uncertainties with special consideration ofboreal regions. Biogeosciences 3:397-420. doi:10.5194/bg3-397-2006

Soil Survey Staff. 2015. Key to Soil Taxonpmy. ${ }^{11}$ th Edition. United States Departement of Agriculture. Natural Ressources Conservation Services.

Subagyo H, Suharta N, Siswanto AB. 2000. Tanah-tanah Pertanian di Indonesia. Halaman 21-26 dalam A. Adimihardja, L. I. Amien, F. Agus, D. Djaenudin (Eds.). Sumberdaya Lahan Indonesia dan Pengelolaannya. Pusat Penelitian dan Pengembangan Tanah dan Agroklimat, Bogor.

Teutscherova N, Vazquez E, Masaguer A, Navas M, M. Scow K, Schmidt R, Benito M. 2017. Comparison of lime- and biochar-mediated $\mathrm{pH}$ changes in nitrification and ammonia oxidizers in degraded acid soil. Biol Fertil Soils, vol. 53:811-821. SpringerVerlag GmbH Germany. (doi:10.1007/s00374-0171222-0).

Xie T, Reddy KR, Wang C, Yargicoglu E, Spokas K. 2015. Characteristics and Applications of Biochar for Environmental Remediation: A Review. Critical Reviews in Environmental Science and Technology, 45:939-969. ISSN: 1064-3389 print/1547-6537 online DOI: 10.1080/10643389.2014.924180.

Xu, N, Tan G, Wang H, Gai X. 2016. Effect of biochar additions to soil on nitrogen leaching, microbial biomass and bacterial community structure. European Journal of Soil Biology, 74: 1-8. http://www.elsevier.com/locate/ejsobi.

Yang X, Liu J, McGrouther K, Huang H, Lu K, Guo X, He L, Lin X, Che L, Ye Z, Wang H. 2015. Effect of biochar on the extractability of heavymetals ( $\mathrm{Cd}, \mathrm{Cu}$, $\mathrm{Pb}$, and $\mathrm{Zn}$ ) and enzyme activity in soil. Environ Sci Pollut Res, 23:974-984. Springer. Online: DOI $10.1007 / \mathrm{s} 11356-015-4233-0$ 